\title{
Levels of selected heavy metals in wheat flour on the ghanaian market: a determination by atomic absorption spectrometry
}

\author{
E. D. Doe ${ }^{1, ~ *}$, A. K. Awua ${ }^{1}$, O. K. Gyamfi ${ }^{1}$, N. O. Bentil ${ }^{2}$ \\ ${ }^{1}$ Radiological and Medical Sciences Research Institute, Cellular and Clinical Research Centre, Ghana Atomic Energy Commission, \\ Legon-Accra-Ghana \\ ${ }^{2}$ National Nuclear Research Institute, Ghana Atomic Energy Commission, Legon-Accra-Ghana
}

\section{Email address:}

dzidey@yahoo.com(E. D. Doe), a_awua@yahoo.com(A. K. Awua), otigyamfi@yahoo.co.uk(O. K. Gyamfi), nashbentil@yahoo.com(N. O. Bentil)

\section{To cite this article}

E. D. Doe, A. K. Awua, O. K. Gyamfi, N. O. Bentil. Levels of Selected Heavy Metals in Wheat Flour on the Ghanaian Market: A Determination by Atomic Absorption Spectrometry. American Journal of Applied Chemistry. Vol. 1, No.2, 2013, pp. 17-21.

doi: 10.11648/j.ajac.20130102.11

\begin{abstract}
Wheat flour is an important source of nutrient and as such is widely consumed in most part of the world, as bread and other pastries. Due to its high consumption, the presence of heavy metal at high concentration would be a significant health risk. Based on the soil in which the wheat was grown and the milling technology employed in making the flour, the heavy metal content of wheat flour varies. In analyzing heavy metal content of flour on the Ghanaian market, (one made in Ghana and another made in Turkey) an atomic absorption spectrophotometric analysis of milestone acid digested flour was used with the appropriate standards. With a 9\% $-100.4 \%$ recovery rate, $\mathrm{Fe}, \mathrm{Zn}, \mathrm{Mn}, \mathrm{Cd}, \mathrm{Pb}$ were detected at varying concentrations in both flour brands, while $\mathrm{Co}, \mathrm{Ni}, \mathrm{Cu}, \mathrm{Cr}, \mathrm{As}, \mathrm{Hg}$ were below detection limits. The levels of the nutritionally important elements such as Fe and $\mathrm{Zn}$ would be beneficial to human health, while those of the toxic element present are not likely to pose any health risk to consumers of this flour.
\end{abstract}

Keywords: Health Risk, Heavy Metals, Milling Technology, Soil, Wheat Flour

\section{Introduction}

Cereals are the main source of food in many countries. With regards to human diet, the most important cereals are wheat (Triticum), rice (Oryza sativa), oats (Avena sativa), barley (Ordeum vulgare), rye (Secale cereale), corn (Zea mays) and millet (Panicum mili-aceum)[1]. Among them, wheat is one of the most consumed[2] and spread. Cultivation of wheat dates back to antiquity, when its harvest was essential for human diet. Today, it highly contributes to the economy and the social structure of a country. Generally speaking, cereals are necessary for a healthy diet and nowadays a daily consumption of between 4 and 6 portions of cereals derived products is recommended due to their content in fiber, trace minerals and vitamins, which are supposed to prevent various diseases[3]. All cereal derived products are rich in carbohydrates, and therefore, the base of a well-balanced and healthy diet. This is reason for the importance of this group of food.

\section{Main Body}

Wheat flour is the product prepared from grain of common wheat, Triticum aestivum L. by grinding or milling processes in which the bran and germ are partly removed and the remainder is comminuted to a suitable degree of fineness. Numerous research reports deposited in the USDA Nutrient Database has shown that wheat flour is rich in proteins, carbohydrates-dietary fibres and sugars, vitamins-Thiamine, Riboflavin, Niacin, acid, Vitamin and Folate, minerals-calcium, iron, magnesium, manganese, phosphorus, potassium, sodium, zinc, copper, selenium and appreciable levels of fats[4]. Table 1

Wheat flour is consumed mainly in products such as bread and other pastries such as cakes and pies. Wheat is so widely used because of an important property: when wheat flour is mixed with water, complex protein gluten develops. 
The gluten development is what gives wheat dough an elastic structure that allows it to be worked in a variety of ways, and which allows the retention of gas bubbles in an intact structure, resulting in a sponge like texture to the final product[5].

Table 1. Wheat flour nutrition information (Minerals amount per 1 cup (120g) selected serving_

\begin{tabular}{lcc}
\hline Minerals & Amount in mg & \% Daily Value \\
\hline Iron & $4.7 \mathrm{mg}$ & $26 \%$ \\
Magnesium & $166 \mathrm{mg}$ & $41 \%$ \\
Phosphorus & $415 \mathrm{mg}$ & $42 \%$ \\
Potassium & $486 \mathrm{mg}$ & $14 \%$ \\
Calcium & 40.8 & $4 \%$ \\
Sodium & $6.0 \mathrm{mg}$ & $0 \%$ \\
Zinc & $3.5 \mathrm{mg}$ & $23 \%$ \\
Copper & $0.5 \mathrm{mg}$ & $23 \%$ \\
Manganese & $4.6 \mathrm{mg}$ & $228 \%$ \\
Selenium & $84.8 \mathrm{mg}$ & $121 \%$ \\
Fluoride & & \\
\hline
\end{tabular}

Source: USDA Nutrient Database Percent Daily Values $(\% \mathrm{DV})$ are for adults or children aged 4 or older, and are based on a 2,000 calorie reference diet.

Depending on the percentage of gluten content in the flour, wheat flour can be classified as being hard or soft; hard flour containing about $12 \%$ to $14 \%$ gluten content, and has elastic toughness that holds its shape well once baked. Soft flour however, is comparatively low in gluten and so results in a finer or crumbly texture[6].

Most of the cultivated varieties of wheat can also be classified depending on their usefulness, but among them hard wheat (Triticum durum) and soft wheat (Triticum aestivum) are the most important. Hard wheat is mostly cultivated in dry areas and richer in proteins, water and calcium than soft wheat. On the other hand, soft wheat can be cultivated in hot or temperate areas and, when it breaks, the grain is harder at edge than in the middle, where it is floury. It contains more fat, starch, iron, phosphorus and vitamin $B$ than hard wheat[3].

The process of flour making involved the use of high technology, which is a source of heavy metal contamination of the products[7]. Also, the wheat used in the production of the flour may have been grown on farmlands with high concentration of heavy metals or the farmland upon which the wheat were grown may have been watered with water from sources with high concentration of heavy metals $[8,9]$. Some of these metals introduced into the wheat flour are essential for the development of life due to their importance in many of the biochemical reactions which are specific in human beings[10] and play a very important role at a pathological level, because their shortfall could produce certain diseases or reduce life expectancy, delay the growth or cause alterations in reproduction. On the other hand, minerals contribute to the flavor, the enzymatic reactions, the texture and the color of food.

Heavy metals such as copper, nickel, chromium and iron, for example, are essential in very low concentrations for the survival of all forms of life. Only when they are present in greater quantities, can these, cause metabolic anomalies. Here, the boundary between the essential and the toxic effect is somewhat problematic[11]. Some elements such as Mn and $\mathrm{Zn}$ are essential micronutrients with a human requirement of not more than a few milligrams per day. However, micronutrients may become harmful when their ingestion rates are too high. In contrast, trace elements such as $\mathrm{Cd}$ and $\mathrm{Pb}$ are well known as toxic if their intake through ingestion or inhalation is excessive. The deficiencies, excesses or imbalances in the supply of inorganic elements from dietary sources can have an important deleterious influence on human health[12]. Since 1973, As, Cu, Cd, Fe, $\mathrm{Hg}, \mathrm{Pb}$, and $\mathrm{Zn}$ have been considered by the joint FAO/WHO Codex Alimentarius Commission to be potentially toxic for human diet with As (as arsenite) being carcinogenic[13].

On the other hand, cereals do also contain heavy metals which, on the contrary, are not essential for the organism, and penetrate through the ground, the air and the water[14]. The importance of these routes of penetration depends on the type of ground and where it is placed and the agricultural practices that have been used.

Essentially, the heavy metals have only become a focus of public interest since analytical techniques have made it possible to detect them even in very small traces. According to the codex standard, wheat flour should be free from heavy metals which may be representing a hazard to human health.

The main characteristics of these trace elements are that they are not biodegradable, have no biological function, are able to accumulate in the organism and generate dysfunctions in the biological system, causing therefore serious problems to the human health. For this reason content of these toxic elements in cereals should be under control.

Research have been carried out on the levels of heavy metals in, vegetables, breast milk, fish, meat, and fruits in the Greater Accra, Eastern, Western and Ashanti regions of Ghana where the levels of $\mathrm{Co}, \mathrm{Cd}, \mathrm{Fe}, \mathrm{Mn}, \mathrm{Cu}, \mathrm{Zn}, \mathrm{Pb}, \mathrm{Ni}$, $\mathrm{Cr}$ and $\mathrm{Pb}$ in the various samples were between below detection limits[15-19].

Fortification is the addition of one or more essential nutrients to food, whether or not it is normally contained in it, for the purpose of preventing or correcting a demonstrated deficiency of one or more nutrients in the population[20]. It is an effective public health strategy. The purpose of this strategy is to increase the intake of a specific nutrient or nutrients that have been identified as inadequate in food supply. Food fortification can be mandatory, that is legislated by law and or regulated, or it can be voluntary, that is, left to the discretion of the food manufacturer[21]. Wheat flour is the only vehicle that has been used extensively for iron fortification around the world. Fortification of wheat flour is simple and cheap and a major strategy for preventing 
anemia.

In Ghana, the main wheat flour on the market is milled by a local company, Takoradi Flour Mill Limited; however, imported fortified wheat flour from Turkey is also on the market. There is little or no information on the levels of heavy metals in the wheat flour manufactured and sold by the Takoradi Flour Mill Limited and the one imported into the country. Thus, this study seeks to assess and compare the concentrations of heavy metals in the wheat flour produced in Ghana and one imported from Turkey with the view of assessing the health risk associated with the consumption of these products.

\section{Materials and Method}

\subsection{Sample Collection}

Samples of flour produced by Takoradi Flour Mill Limited, Ghana and Wheat Flour Manufacturer Company Limited, Turkey was purchased from the Madina market.

\subsubsection{Atomic Absorption Spectrophotometer}

\section{Determination}

Analysis of heavy metals of interest was performed using an Atomic Absorption Spectrophotometer (Varian AA240 FS) with the recommended instrument parameters including detection limits for each metal determined (table 2).

Table 2. Recommended instrument parameters-atomic absorption working conditions (fixed).

\begin{tabular}{lllll}
\hline Element & $\begin{array}{l}\text { Lamp } \\
\text { Current } \\
(\mathrm{mA})\end{array}$ & $\begin{array}{l}\text { Waveleng } \\
\text { th }(\mathrm{nm})\end{array}$ & $\begin{array}{l}\text { Slit } \\
\text { Width } \\
(\mathrm{nm})\end{array}$ & $\begin{array}{l}\text { Instrument } \\
\text { detection } \\
(\mathrm{mg} / \mathrm{l})\end{array}$ \\
\hline $\mathrm{Co}$ & 7 & 240.7 & 0.2 & 0.0050 \\
$\mathrm{Cd}$ & 4 & 228.8 & 0.5 & 0.0020 \\
$\mathrm{Fe}$ & 5 & 248.3 & 0.2 & 0.0060 \\
$\mathrm{Mn}$ & 5 & 279.5 & 0.2 & 0.0020 \\
$\mathrm{Cu}$ & 4 & 324.7 & 0.5 & 0.0030 \\
$\mathrm{Zn}$ & 5 & 213.9 & 1.0 & 0.0010 \\
$\mathrm{~Pb}$ & 5 & 217.0 & 1.0 & 0.0010 \\
$\mathrm{Ni}$ & 4 & 232.0 & 0.2 & 0.0010 \\
$\mathrm{Cr}$ & 7 & 357.9 & 0.2 & 0.0010 \\
$\mathrm{As} \quad(B y$ & 10 & 193.7 & 0.5 & 0.0010 \\
$\mathrm{Hydride})$ & & & & \\
$\mathrm{Hg} \quad(B y$ & 4 & 253.7 & 0.5 & 0.0010 \\
$\mathrm{Hydride})$ & & & & \\
\hline
\end{tabular}

Fuel $=$ Acetylene, Support $=$ Air

\subsection{Digestion Protocol}

The Milestone Acid Digestion procedure was used, where $0.50 \mathrm{~g}$ of the each flour sample was weighed into a Teflon beaker. Concentrated Nitric acid $(6 \mathrm{ml}, 65 \%)$ and $1 \mathrm{ml}$ Hydrogen peroxide (30\%) were then added. The Teflon beakers were covered with Teflon cups and loaded onto rotor and tightly secured using a rench or torque. The rotor was then placed in ETHOS 900 microwave oven and digested using the digestion programme presented in table 3 below.

Table 3. Milestone acid digestion programme

\begin{tabular}{llll}
\hline Step & Time (mins.) & Power & Pressure \\
\hline 1 & 2 & 250 & 100 \\
2 & 2 & 0 & 100 \\
3 & 6 & 250 & 100 \\
4 & 5 & 400 & 100 \\
5 & 5 & 600 & 100 \\
\hline
\end{tabular}

Temperature 1 and 2 were $400 \mathrm{oC}$ and $500 \mathrm{oC}$

\section{Results and Discussion}

The validity of the data generated in this study was checked using reference materials spiked with known concentrations of the targeted elements. These were taken through the same extraction and other processes as the flour samples were. The percentage of standards element detected where high and within acceptable limits, 95\% to $100.4 \%$ (table 4).

Implying a maximum under recovery of $5 \%$ particularly for the amounts of As and Mn and over estimation of $0.4 \%$ for $\mathrm{Cr}$ was possible in this study.

The specific percentage recovery of each of the elements targeted in this study is presented in table 4. Samples were analyzed in triplicates and at separate times. Each time with a new blank preparation and standards solution of the element prepared.

Of the eleven (11) heavy metal analyzed for, five (Fe, $\mathrm{Zn}$, $\mathrm{Mn}, \mathrm{Cd}, \mathrm{Pb}$ ) were detected in appreciable quantities in both flour brands while the other six $(\mathrm{Co}, \mathrm{Ni}, \mathrm{Cu}, \mathrm{Cr}, \mathrm{As}, \mathrm{Hg})$ if present were below the detection limits. The amounts of the detected elements are presented in figure 1 (below) as means with error bars indicating the standard deviation of the means. The amount of Fe in the flour made in Turkey (FMT) was almost four-fold of that in the flour made in Ghana (FMG) as depicted in figure 1.

Table 4. Recovery rate for the selected heavy metals as determined with quality control standards.

\begin{tabular}{llllllllllll}
\hline STD-QC & $\mathrm{Fe}$ & $\mathrm{Zn}$ & $\mathrm{Mn}$ & $\mathrm{Cd}$ & $\mathrm{Pb}$ & $\mathrm{Co}$ & $\mathrm{Ni}$ & $\mathrm{Cu}$ & $\mathrm{Cr}$ & $\mathrm{As}$ & $\mathrm{Hg}$ \\
\hline \% Recovery & 99.9 & 97.6 & 95.0 & 99.7 & 100.0 & 99.5 & 99.8 & 100.0 & 100.4 & 95.0 & 100.0 \\
\hline
\end{tabular}

This makes FMT relatively and potentially a better source of dietary iron. While the FMT flour were fortified with iron, according to the manufacturer, the iron content of the FMG may have resulted from the uptake of iron from the soil by the wheat used in making that flour or that the type of wheat processing technology employed during milling resulted in the retention of the iron content part of the wheat in the flour. As referenced in[20], fortification of food is to increase the intake of a specific nutrient or nutrients that have been identified as inadequate in food 
supply. Thus, the fortified wheat when consumed could help in preventing anemia[21].

The amount of Mn in the FMG was slightly higher but not significantly $(p<0.05)$ more than that in the FMT; the only element that was found in greater amounts in the FMG.

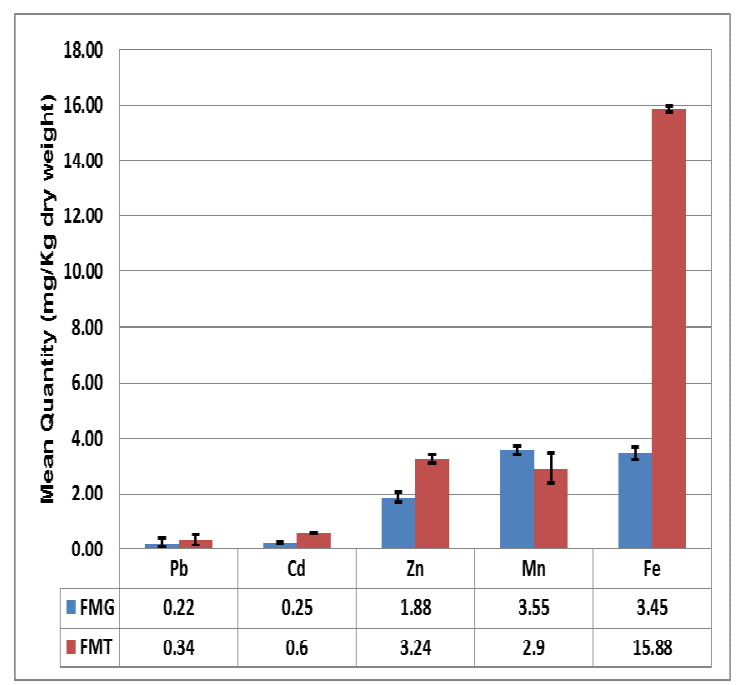

Fig 1. Quantities of heavy metals detected at substantial levels in two wheat flour on the Ghanaian market. Errors are $\pm S D ; F M G=$ flour made in Ghana; FMT = flour made in Turkey.

However, comparing these amounts of $\mathrm{Mn}(3.55 \mathrm{mg} / \mathrm{kg}$ and 2.9 mg.kg for FMG and FMT respectively) in these to those reported by[22] for flour made in Pakistan (ranging between $20.2 \mathrm{mg} / \mathrm{kg}$ and $38.1 \mathrm{mg} / \mathrm{kg}$ ), those detected in this study are very low.

Another nutritionally important element detected in both flour brands was $\mathrm{Zn}$. The amount of $\mathrm{Zn}$ in the FMT was $3.24 \mathrm{mg} / \mathrm{kg}$ and was about twice $(p<0.05)$ that in the FMG $(1.88 \mathrm{mg} / \mathrm{kg})$. However, these amounts were smaller than those reported by analyses of flour made in Ethiopia, between $6.00 \mathrm{mg} / \mathrm{kg}$ and $9.90 \mathrm{mg} / \mathrm{kg}$; USA, between 7.0 $\mathrm{mg} / \mathrm{kg}$ and $7.2 \mathrm{mg} / \mathrm{kg}$; Romania, $13.97 \mathrm{mg} / \mathrm{kg}$,[23] and Nigeria, $0.019 \mathrm{mg} / \mathrm{kg}$ and $2.93 \mathrm{mg} / \mathrm{kg}[24]$. The toxic elements $\mathrm{Cd}$ and $\mathrm{Pb}$ were also detected but at lower amounts. The $\mathrm{Cd}$ in the flour made in Turkey was more than twice that in the flour made in Ghana $(0.6 \mathrm{mg} / \mathrm{kg}$ and $0.25 \mathrm{mg} / \mathrm{kg}$ respectively). These amounts were relatively higher compared to those reported by other studies in Africa of wheat flour; Nigeria, between $0.0004 \mathrm{mg} / \mathrm{kg}$ and $0.002 \mathrm{mg} / \mathrm{kg}$ and Ethiopia, between $0.011 \mathrm{mg} / \mathrm{kg}$ and 0.024 $\mathrm{mg} / \mathrm{kg}[23]$.

However, the amount for the flour made in Turkey was within the range of the amounts of $\mathrm{Cd}$ detected in flour made in Pakistan $(0.379 \mathrm{mg} / \mathrm{kg}$ and $0.73 \mathrm{mg} / \mathrm{kg})[22]$. Also, these amounts were higher than the CODEX general standard for foods[25] and the EC regulation for $\mathrm{Cd}$ in food[26] both of which are $0.2 \mathrm{mg} / \mathrm{kg}$. Similarly, the amount of $\mathrm{Pb}$ detected in the flour made in Ghana and Turkey studied herein $(0.22 \mathrm{mg} / \mathrm{kg}$ and $0.34 \mathrm{mg} / \mathrm{kg}$ respectively), were slightly higher than the CODEX general standard and the EC regulation for $\mathrm{Pb}$ in food, which are both $0.2 \mathrm{mg} / \mathrm{kg}$. It is worth noting that $\mathrm{Pb}$ was not detected in the Nigerian study. The following elements $\mathrm{Co}, \mathrm{Ni}, \mathrm{Cu}$, $\mathrm{Cr}$, As and $\mathrm{Hg}$ were below detection limits in both the flour made in Ghana and Turkey. However, these elements were detected in flour made in Pakistan[22].

Since flour is a key ingredient in bread and pastries, which are staple food in most developing countries, it is estimated that the average young adult would consume about $500 \mathrm{~g}$ of flour in flour food product in a day. With these amounts of elements and the estimated consumption of flour food product the level of intake of the toxic element would be below the minimum allowable intake. It is being professed that the presence of $\mathrm{Pb}$ and $\mathrm{Cd}$ needs to be monitored since bioaccumulation of these heavy metals may occur over a long time.

\section{Conclusion}

The heavy metal content of the flour made in Ghana and that made in turkey (available on the Ghanaian market) where very similar but varied in terms of the individual concentration of the metal elements. The very high iron content of the flour made in Turkey confirmed its labeling that stated it was fortified and as such will be of health benefit if this flour is used. The levels of the other nutritionally important element such as $\mathrm{Zn}$ are also beneficial to human health. The levels of the toxic element present are not likely to pose any health risk to consumers of this flour.

\section{Acknowledgments}

We are thankful to Ophelia Kai Adjei and Kingsley Kwame Nsowah for their assistance.

\section{References}

[1] García-Villanova B, Guerra EJ. Cereales y productos derivados. In Tratado de nutrición, Tomo II: Composición y Calidad Nutritiva de los Alimentos. Gil A. Eds., Ed. Acción Médica Grupo; 2005; pp. 177-228.

[2] Araujo RGO, Dias F, Macedo SM, Dos Santos WNL, Ferreira SLC. Method development for the determination of manganese in wheat flour by slurry sampling flame atomic absorption spectrometry. Food Chem 2007; 101: 397-400

[3] Callejo MJ. Industrias de cereales y derivados. 1st ed., AMV Ediciones, Mundi-Prensa España; 2002.

[4] Haytowitz, D.B., Lemar, L.E., Pehrsson, P.R., Exler, J., Patterson, K.K., Thomas, R.G., Nickle, M.S., Williams, J.R., Showell, B.A., Khan, M., Duvall, M., Holden, J.M. 2011. USDA National Nutrient Database for Standard Reference, Release Available: http://www.ars.usda.gov[Accessed 24th April 2012].

[5] Makinson J. H, Greenfeld H, Wills R. B. H. Composition of Australian foods, sweet and savoury biscuits. Food Australia, 
1989, 41: 802-807.

[6] Chu, M. 2004. "Wheat Flour" Cooking for Engineers. CFE enterprise Inc. retrieved online a http://www.cookingforengineers.com/article/63/wheatflour[ Accessed 2nd May 2012].

[7] Gulfrazi M, Mussaddeq Y, Kahnum R, Ahmad T. Metal contamination in wheat's crops irrigated with industrial efficient. J. Biol. Sci., 2003,.3: 335-339.

[8] Smith C. J, Hopmans O, Cook F.J. Accumulation of Cr, Pb, $\mathrm{Cu}, \mathrm{Mn}, \mathrm{Zn}$ and $\mathrm{Cd}$ in soil following Irrigation with Treated effluent in Australia. J. Environ. Pollut., 1996, 94: 317-323.

[9] Osu C. J, Odeemelamo S.A. Heavy metals (Pd, Cd, As and $\mathrm{Ag})$ contamination of Edible grain grown and marketed in Nigeria. Resource J. Applied Sci., 2007, 2: 192-195.

[10] Singh V, Garg AN. Availability of essential trace elements in Indian cereals, vegetables and spices using INAA and the contribution of spices to daily dietary intake. Food Chem 2006; 94: 81-89.

[11] Darmono D, Denton G. R. W. Heavy Metal Concentrations in the Banana, Prawn, Peneaus merguiensis, and leader Prawn, P. monodon, in the townsville region of Australia. Bull. Environ. Contam, Toxicol,. 1990, 44: 479-486.

[12] WHO/IAEA/FAO, 1996.Trace elements in human nutrition and health, WHO, in collaboration with FAO and IAEA, Geneva

[13] Al-gahri M. A, Almussali M. S. Microelement Contents of Locally Produced and Imported Wheat Grains in Yemen. E-Journal of Chemistry, 2008,5 (4): 838-843

[14] Golia EE, Dimirkou A, Mitsios IK. Influence of some soil para- meters on heavy metals accumulation by vegetables grown in agricultural soils of different soil orders. B Environ Contam Tox 2008; 81: 80-84.

[15] Anim A.K., Ahialey E.K., Duodo G.O., Ackah M, Bentil N.O. Accumulation Profile of Heavy Metals in Fish Samples from Nsawam, Along the Densu River,Ghana, Research Journal of Envt. and Earth Sciences, 2011, 3(1):56-60.

[16] Bempah C. K, Buah-Kwofie A, Osei-Tutu A, Denutsui D, Enimil E, Adjei-Martey G, Blewu B and Asomaning J..Pesticide residues and heavy metals levels in some selected fruits and vegetables from Ghanaian markets. Elixir Food Science, 2011,39: 4964-4972

[17] Koranteng-Addo E. J, Bentum J. K, Sackitey O. J, Tuffuor J.K, Essumang D. K, Owusu-Ansah E.. Lead, Cadmium and Arsenic in breast milk of lactating mothers in Odumanse-Atua community in Manya Krobo district of eastern region of Ghana. J. Chem. Pharm. Res., 2010, 2(5): $16-20$.

[18] Odai, S. N, Mensah E, Sipitey D, Shoji R, Awuah E. Heavy Metals Uptake by Vegetables Cultivated on Urban Waste Dumpsites: Case Study of Kumasi, Ghana. Research Journal of Environment and Toxicology. 2008, 2(2): 9299.

[19] Essumang D. K, Dodoo D. K, Obiri S, Yaney, J. Y. Analysis of Arsenic, Cadmium and Mecury in Cocoyam (Colocasia esculenta) and Water Cocoyam (Xanthosoma sagittifolium) in a Mining Community. Bull. Environ. Contam. Toxicol. 2007, 9 (4): $377-379$

[20] FAO/WHO 1999. Joint FAO/WHO Expert Committee on Food Additives,53rd meeting WHO,Geneva,Switzerland.

[21] Nestel P, Davidson L, Anemia, Iron deficiency and Iron deficiency anemia 2002 INAGG/ILSI Press, Washington DC

[22] Shar G. Q, Kazi T. G, Jakhrani M. A, Sahito, Memon M. A. Determination of seven heavy metals, Cadmium, Cobalt, Chromium, Nickel, Lead, Copper and Manganese in Wheat flour samples by Flame Atomic Absorption Spectrometry. Jour. Chem Soc. Pak., 2002, 24(2): 265.

[23] A PhD Thesis: Tadesse Z.. Levels of trace Cadmium and essential Zinc in wheat flour commercially available in Addis Ababa, Ethiopia. Addis Ababa University School of Graduate Studies Department of Chemistry. July, 2006

[24] Cuadrado, C. J, Kumpulainen A., Carbajal O. Moreiras. Cereals contribution to the total dietary intake of heavy metals in Madrid,Spain. J. Food Compos. Anal, 2000, 13: 495-503.

[25] Codex General Standard for Contaminants and Toxin in Foods, CODEX, STAN 193-1995. , 2006.

[26] European Commission Regulation (EC) No. 1881/2006 of 19 December 2006, setting maximum levels for certain contaminants in foodstuffs. 